\title{
Numerical Analysis of Relationships among Rapidly Growing, Scotochromogenic Mycobacteria
}

\author{
By M. TSUKAMURA AND S. MIZUNO \\ The National Chubu Hospital, Obu, Aichi, Japan 474
}

(Received 4 August 1976; revised I4 September 1976)

SUMMARY

Numerical analysis of the relationships among rapidly growing, scotochromogenic mycobacteria was carried out; a dendrogram was prepared by a single linkage method and the separation between species was tested. The following were distinct species: Mycobacterium aichiense; Mycobacterium rhodesiae; Mycobacterium chubuense; Mycobacterium obuense; Mycobacterium gilvum; Mycobacterium duvalii; Mycobacterium flavescens; and Mycobacterium vaccae. Mycobacterium tokaiense was reduced to a synonym of $M$. chubuense. Mycobacterium parafortuitum, Mycobacterium aurum and Mycobacterium neoaurum were considered to be subspecies of $M$. parafortuitum or part of a $M$. parafortuitum complex.

The separation between species was tested by comparing the extent of overlap of one species with that of another. When two species showed no such overlap, they were regarded as distinct. The results of the test of separation agreed well with taxonomic relationships shown by the dendrogram. Characters useful for differentiating the spacies were found.

\section{INTRODUCTION}

Mycobacterium phlei Lehmann \& Neumann I899 was the first species of rapidly growing scotochromogenic mycobacteria to be described. This organism and Mycobacterium thermoresistibile Tsukamura 1966 are the only two rapidly growing mycobacteria that are able to grow at $52{ }^{\circ} \mathrm{C}$. Hence, differentiation of these from other mycobacteria is easy (Tsukamura, 1971) and they were not included in this study. Rapidly growing, scotochromogenic mycobacteria recently described include Mycobacterium flavescens Bojalil, Cerbon \& Trujillo 1962, with Mycobacterium acapulcensis Bojalil et al. 1962 being regarded as a synonym of $M$. flavescens (Tsukamura, I968), Mycobacterium vaccae Bönicke \& Juhasz I964, Mycobacterium parafortuitum Tsukamura, Toyama \& Mizuno I965, Mycobacterium aurum Tsukamura \& Tsukamura 1966, Mycobacterium obuense Tsukamura \& Mizuno I97 I Mycobacterium rhodesiae Tsukamura, Mizuno, Gane, Mills \& King I97 I, Mycobacterium gilvum Stanford \& Gunthorpe 197I, Mycobacterium duvalii Stanford \& Gunthorpe 1971, Mycobacterium neoaurum Tsukamura 1972, Mycobacterium aichiense Tsukamura 1973, Mycobacterium chubuense Tsukamura 1973, and Mycobacterium tokaiense Tsukamura 1973. All grow rapidly and form yellow- or orange-pigmented, wet and smooth colonies, except for $M$. flavescens which usually forms rough colonies and $M$. parafortuitum which sometimes forms only slightly pigmented, mucoid colonies.

The purposes of this study were to clarify the taxonomic relationships among these species by numerical analysis and to report the characteristics of $M$. aichiense, $M$. chubuense and $M$. neoaurum which have only been described in Japanese. A comparison of the 


\section{Table I. Strains of rapidly growing, scotochromogenic mycobacteria}

\begin{tabular}{|c|c|c|c|}
\hline Species & $\begin{array}{l}\text { Abbrevi- } \\
\text { ation }\end{array}$ & $\begin{array}{c}\text { Strain } \\
\text { numbers }\end{array}$ & $\begin{array}{l}\text { Recognized strains and their } \\
\text { code numbers } \dagger\end{array}$ \\
\hline M. flavescens & FL & OI-IO & or, АTCCI $4474^{*} ; 09$, ATCCI 4473 \\
\hline M. vaccae & VA & OI-I 2 & $\begin{array}{l}\text { OI, ATCCI } 5483^{*} ; \text { 02, ATCCI } 3034 ; 03, \text { ATCC23002; 04, } \\
\text { ATCC23004; 05, Bönicke2746; O6, Bönicke2722; 07, } \\
\text { Bönicke2742-6; 08, Bönicke2743-4; 09, Bönicke2744-6; } \\
\text { IO, Bönicke2747; I I, ATCC23014; 12, ATCC23027 }\end{array}$ \\
\hline M. parafortuitum & PA & $0 \mathrm{I}-06$ & $\begin{array}{l}\text { 02, ATCCI9688; O5, ATCC19687 }=\text { NCTC104IO; 06, ATCC } \\
19686=\text { NCTCI04II* }\end{array}$ \\
\hline M. aurum (type A) & AA & $0 \mathrm{I}-06$ & $\begin{array}{l}\text { 04, } \operatorname{ATCC} 25790=\text { NCTC10440*; 05, ATCC2580I ; 06, ATCC } \\
25802\end{array}$ \\
\hline M. auru & & OI-I 2 & 03, ATCC27277 \\
\hline M. chubuense & $\mathrm{CH}$ & OI-I 5 & 13, ATCC27278 $=$ NCTC10819*; 15, ATCC27279 \\
\hline M. obuense & OB & $0 \mathrm{I}-05$ & $05, \mathrm{ATCC} 27023=\mathrm{NCTCI} 1078^{*}$ \\
\hline M. rhodesiae & $\mathbf{R H}$ & $0 I-16$ & 06, ATCC27024* \\
\hline M. gilvum & GI & $\mathrm{OI}-05$ & $\begin{array}{l}\text { ol, Stanford } 392 ; \text { 02, Stanford } 35=\text { NCTC10 } 742^{*} ; 03 \text {, } \\
\text { Stanford132; 04, Stanford } 205 ; 05 \text {, Stanford } 391\end{array}$ \\
\hline M. duvalii & DU & $0 \mathrm{I}-04$ & $\begin{array}{l}\text { OI, Stanford } 51=\text { NCTC } 8645 ; \text { 02, Stanford } 70=\text { NCTC } 35^{*} ; \\
\text { o3, Stanford } 579=\text { NCTC } 509 ; 04, \text { Stanford } 580=\text { NCTC } 514\end{array}$ \\
\hline M. neoaurum & $\mathrm{NE}$ & $0 I-19$ & $\begin{array}{l}\text { o1, ATCC25796; I5, ATCC25791; 16, ATCC25795 }=\text { NCTC } \\
\text { I08I } 8^{*} ; \text { 17, ATCC25799; I8, ATCC25800; 19, ATCC25798 }\end{array}$ \\
\hline M. $a$ & A & $0 \mathrm{I}-08$ & $02, \operatorname{ATCC} 27281 ; 06, \operatorname{ATCC} 27280=$ NCTCI0820* \\
\hline$M$. & TO & $01-03$ & OI, $\operatorname{ATCC} 27282=$ NCTCI0821* \\
\hline
\end{tabular}

classification by cluster analysis and by the 'separation between species' test (Tsukamura, 1976) was also attempted.

\section{METHODS}

Strains. The original designations and sources of the I2I strains of rapidly growing, scotochoromogenic mycobacteria which were studied are given in Table $\mathrm{I}$.

Characters. A total of 80 characters were tested in all the strains. Of the tests previously described (Tsukamura, I967), tests 59 to 68,76 to 87,92 and 93 were omitted and the following nine tests added: (I) $\alpha$-esterase; (2) $\beta$-esterase; (3) resistance to $5 \mu \mathrm{g}$ ethambutol per ml Ogawa egg medium; $(4,5)$ tolerance to $0 . \mathrm{I} \%$ and $0.2 \%(\mathrm{w} / \mathrm{v}) \mathrm{NaNO}_{2}$ in Sauton agar; (6) tolerance to $I \%(v / v)$ Tween 80 in Sauton agar; (7) cord formation; (8) utilization of raffinose as sole carbon source; (9) utilization of nicotinamide as dual nitrogen and carbon sources. The methods used were described previously (Tsukamura, 1967, 1969). The esterase activities were tested according to a modification (Tsukamura, Mizuno \& Murata, 1972) of the method of Käppler (1965). The characters were tested three times in each strain; if the results of all three replicates were not the same, the results shown by two of three were recorded.

Numerical analysis. Matching coefficients ( $M$ values) were calculated using the following equation:

$$
\mathrm{M}(\%)=\left[n_{s} /\left(n_{s}+n_{d}\right)\right] \times 100
$$

in which $n_{s}$ is the number of characters in which two test strains show similar code symbols and $n_{d}$ is the number of characters in which two strains show different code symbols. The $M$ values among the strains were calculated using a NEAC 2200 computer (Nippon 
Electric Company, Tokyo, Japan). Clustering was achieved by a single linkage method (Sokal \& Sneath, 1963).

The method described by Tsukamura (1976) was used to test whether or not the species formed by cluster analysis were clearly separable from each other. A 'hypothetical median organism' (HMO) (Liston, Wiebe \& Colwell, 1963) was prepared for each species, and matching $M$ values were estimated for the strains of each species to the HMO of their own species and to the HMO patterns of other species. The mean of M values $(\overrightarrow{\mathrm{M}})$ and standard deviation (s) were calculated for the strains of every species to all HMO patterns. The range of a species was expressed as $(\bar{M} \pm 2 s)$.

\section{RESULTS}

Cluster analysis

In the dendrogram prepared by analysis of 80 characters, $M$. aichiense (2), $M$. rhodesiae (3), M. chubuense (4), M. obuense (5), M. gilvum (6), M. duvalii (7), M. flavescens (8) and $M$. vaccae (9) appear as separate clusters (Fig. I). Most of the clusters were separated at the $92 \%$ similarity level, and the clusters of $M$. aichiense and $M$. rhodesiae at the $94 \%$ level. Mycobacterium tokaiense was included in the cluster of $M$. chubuense. A strain of $M$. gilvum (GIO4) was placed in the cluster of $M$. aichiense. Mycobacterium parafortuitum, $M$. aurum (both types) and $M$. neoaurum were combined into one cluster at the $92 \%$ level. Within this cluster, I I strains of $M$. neoaurum formed a subcluster. All strains of $M$. parafortuitum, except for one, were placed outside the cluster consisting of $M$. aurum and $M$. neoaurum. Two types of $M$. aurum which differed in their reactions in the nitrate reduction test were not separated in the dendrogram.

\section{Separation between species by a statistical method}

The separation of species was tested by comparing the ranges $(\bar{M} \pm 2 s)$ of various species with each other. Mean $M$ values of members of various species and their standard deviations are shown in Table 2. The range of $M$. aurum (type A) overlapped with the range of $M$. aurum (type B), $M$. neoaurum and $M$. parafortuitum but was separated from all others. $M y c o b a c t e r i u m$ aurum (type B) was not separated from $M$. aurum (type A), $M$. neoaurum and $M$. parafortuitum. Mycobacterium neoaurum was not separated from $M$. aurum (both types), but it was separated from all other species including $M$. parafortuitum. Mycobacterium parafortuitum was not separated from $M$. aurum (both types), $M$. neoaurum and $M$. rhodesiae, but it was separated from all others. Mycobacterium aichiense was not separated from $M$. gilvum. Mycobacterium chubuense was not separated from $M$. tokaiense. Mycobacterium tokaiense was not separated from $M$. chubuense. Mycobacterium gilvum was not separated from $M$. aichiense, $M$. chubuense, $M$. tokaiense, $M$. duvalii and $M$. flavescens. Mycobacterium obuense, $M$. rhodesiae, $M$. duvalii, $M$. vaccae and $M$. flavescens were separated from all other species.

\section{Characters useful for distinguishing the species}

Characters useful for differentiating the species are shown in Table 3.

The characters common to all species are: Gram-positive; acid-fast; growth at 28 and $37{ }^{\circ} \mathrm{C}$; occur as rods, short rods and coccoids; form yellow or orange scotochromogenic colonies (M. parafortuitum shows pale yellow rather than the typical yellow colonies); growth within 3 days; tolerant to $0.2 \%$ picric acid or $0.1 \% \mathrm{NaNO}_{2}$ in Sauton agar, $\mathrm{I} \%$ Tween 80 in Sauton agar, $0.05 \%$ sodium salicylate in Ogawa egg medium, and $10 \mu \mathrm{g}$ thiophene-2-carboxylic acid hydrazide per $\mathrm{ml}$ Ogawa egg medium; utilize acetate, pyruvate, 
N ansosu. $N$ II

-

-

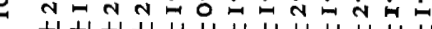
suวosaxpy $W$ $\|$ 更 $+1+1+1+1+1+1+1+1+1+1+1$

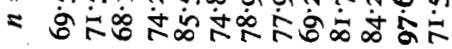
운

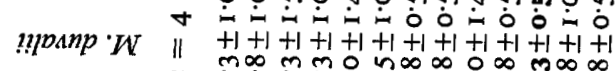
- in

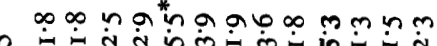

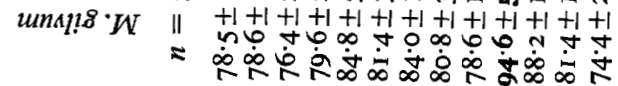

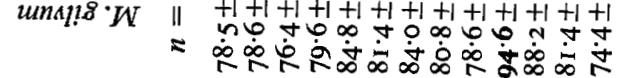
nnmamagtrmmn

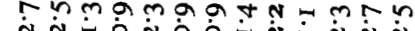
asuanqo $W$ in $+1+1+1+1+1+1+1+1+1+1+1+1+1$

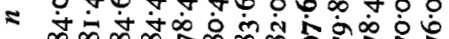
क

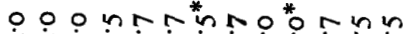

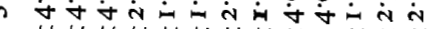
asua!byo1 $W \|+1+1+1+1+1+1+1+1+1+1+1+1+1$

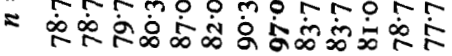

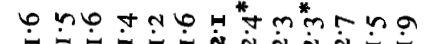
asuanqnyo $2 \pi$ II =

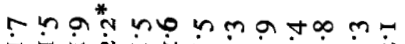
apisapoys $W \stackrel{6}{2} \dot{+}+1+1+1+1+1+1+1+1+1+1+1+1$ $\therefore$ के

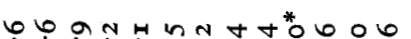

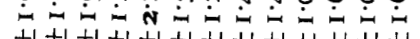
asua!यग! $W$ II $+1+1+1+1+1+1+1+1+1+1+1+1+1$

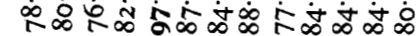
* ${ }^{*} \infty$ on

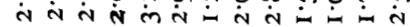



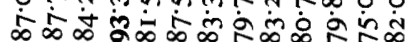
* * ${ }^{*}{ }^{*}$

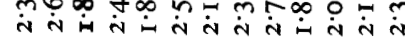
unınпоги. $W$ त $+1+1+1+1+1+1+1+1+1+1+1+1+1$ $\infty$ óm marn?

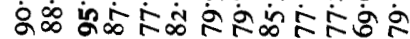
* N * *

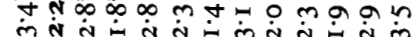

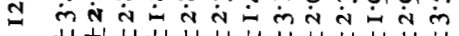

(g) unand $W$ II $+1+1+1+1+1+1+1+1+1+1+1+1+1$

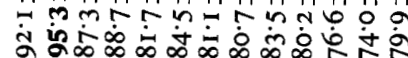
$+1+1+1+1+1+1+1+1+1+1+1$ uomutonoson nn

- in厶大்

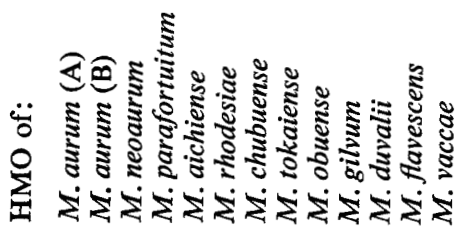


Table 3. Comparison of characters among species of rapidly growing, scotochromogenic mycobacteria

Percentage of strains showing positive character

Character

$\begin{array}{llllllll}\text { No. of strains } & \ldots & 6 & 12 & 19 & 6 & 8 & 15\end{array}$

$\begin{array}{lllllll}\text { Nitrate reduction } & 0 & 100 & 5 & 67 & 0 & 100\end{array}$

$\begin{array}{lrrrrrr}\text { Arylsulphatase (3 day) } & 0 & 59 & 0 & 50 & 100 & 7 \\ \text { Arylsulphatase (2 week) } & 100 & 100 & 21 & 100 & 100 & 100\end{array}$

$\alpha$-Esterase

$\beta$-Esterase

Acetamidase

Benzamidase

Isonicotinamidase

Nicotinamidase

Pyrazinamidase

Allantoinase

PAS degradation $\uparrow$

$\begin{array}{rrrrr}0 & 0 & 21 & 0 & 0 \\ 100 & 100 & 100 & 100 & 50\end{array}$

o

$\begin{array}{lllll}100 & 75 & 90 & 83 & 0\end{array}$

$\begin{array}{lllll}0 & 8 & 0 & 0 & 0 \\ 0 & 0 & 0 & 0 & 0\end{array}$

o

o

$\begin{array}{llll}83 & 67 & 100 & 100\end{array}$

$\begin{array}{llll}83 & 67 & 100 & 100\end{array}$

$\begin{array}{llll}83 & 67 & 74 & 17\end{array}$

0

0
73

73
87
0

Sole source of carbon:

$\begin{array}{lrrrrrrrrrrrrr}\text { Galactose } & 17 & 25 & 53 & 0 & 0 & 0 & 0 & 0 & 0 & 0 & 100 & 0 & 8 \\ \text { Arabinose } & 67 & 92 & 100 & 67 & 0 & 0 & 100 & 0 & 0 & 0 & 100 & 0 & 8 \\ \text { Xylose } & 67 & 92 & 100 & 100 & 0 & 93 & 100 & 0 & 0 & 0 & 80 & 100 & 0 \\ \text { Rhamnose } & 0 & 0 & 84 & 17 & 0 & 87 & 100 & 0 & 0 & 0 & 0 & 0 & 100 \\ \text { Trehalose } & 50 & 25 & 79 & 50 & 0 & 13 & 0 & 75 & 10 & 0 & 100 & 0 & 8 \\ \text { Inositol } & 100 & 100 & 100 & 67 & 38 & 13 & 67 & 0 & 0 & 100 & 60 & 100 & 0 \\ \text { Sorbitol } & 0 & 0 & 0 & 0 & 0 & 93 & 100 & 0 & 100 & 0 & 100 & 0 & 0 \\ \text { Malate } & 100 & 100 & 100 & 100 & 100 & 100 & 100 & 100 & 0 & 20 & 100 & 100 & 100 \\ \text { Malonate } & 0 & 0 & 0 & 0 & 0 & 0 & 67 & 0 & 0 & 0 & 0 & 0 & 0 \\ \text { Fumarate } & 100 & 100 & 100 & 100 & 100 & 100 & 100 & 100 & 0 & 20 & 100 & 100 & 83 \\ \text { Citrate } & 0 & 0 & 0 & 33 & 0 & 0 & 0 & 0 & 0 & 0 & 0 & 100 & 8 \\ \text { Propylene glycol } & 100 & 100 & 95 & 100 & 38 & 100 & 100 & 25 & 0 & 80 & 100 & 100 & 100 \\ \text { Sucrose } & 0 & 17 & 5 & 33 & 13 & 100 & 100 & 100 & 0 & 80 & 100 & 0 & 83\end{array}$

Sole sources of carbon and nitrogen:

Serine

Glucosamine

Acetamide

Monoethanolamine

$\begin{array}{rrrrrr}0 & 0 & 0 & 0 & 0 & 53 \\ 83 & 100 & 100 & 100 & 75 & 100 \\ 67 & 50 & 95 & 0 & 0 & 0 \\ 100 & 100 & 68 & 0 & 0 & 0 \\ 100 & 100 & 100 & 100 & 0 & 100\end{array}$

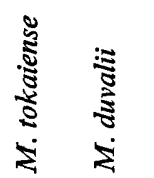
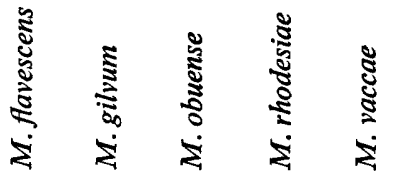

Trimethylenediamine

$\begin{array}{rr}3 & 4 \\ 0 & 100 \\ 0 & 0 \\ 100 & 0 \\ 0 & 100 \\ 33 & 100 \\ 0 & 0 \\ 0 & 0 \\ 0 & 0 \\ 33 & 100 \\ 33 & 100 \\ 33 & 0 \\ 0 & 0\end{array}$

$\begin{array}{rr}10 & \\ 100 & 80 \\ 0 & \\ 100 & 50 \\ 100 & 40 \\ 100 & 100 \\ 0 & \\ 0 & \\ 0 & \\ 20^{*} & 80 \\ 20^{*} & 100 \\ 0 & 60 \\ 0 & \\ & \\ 0 & \\ 0 & \\ 0 & \\ 0 & \\ 10 & \\ 0 & 100 \\ 100 & \\ 0 & \\ 0 & \\ 0 & \\ 0 & \\ 0 & 80 \\ 0 & 80\end{array}$

5
80
0

16

Resistance to

$\mathrm{NH}_{2} \mathrm{OH} . \mathrm{HCl}$ :

$0.125 \mathrm{mg} \mathrm{ml}^{-1}$

$0.25 \mathrm{mg} \mathrm{ml}^{-1}$

$0.5 \mathrm{mg} \mathrm{ml}^{-1}$

$$
\begin{array}{rrrrrr}
100 & 100 & 100 & 100 & 38 & 20 \\
100 & 100 & 69 & 33 & 13 & 0 \\
50 & 67 & 5 & 0 & 0 & 0
\end{array}
$$

$\begin{array}{rr}0 & 0 \\ 67 & 100\end{array}$

$\begin{array}{rrrrr}0 & 0 & 0 & 0 & 0 \\ 0 & 100 & 100 & 100 & 0 \\ 0 & 0 & 0 & 0 & 0 \\ 0 & 0 & 60 & 0 & 0 \\ 0 & 60 & 100 & 100 & 0\end{array}$

Resistance to

$\begin{array}{rrrrrrr}0 & 0 & 100 & 0 & 20 & 100 & 100 \\ 0 & 0 & 0 & 0 & 0 & 44 & 100 \\ 0 & 0 & 0 & 0 & 0 & 25 & 100 \\ 0 & 0 & 0 & 0 & 100 & 100 & 92\end{array}$

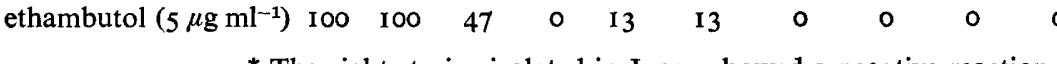

* The eight strains isolated in Japan showed a negative reaction.

$\dagger p$-Aminosalicylate degradation. 
glycerol, glucose, fructose, mannose and mannitol as the sole carbon source in the presence of $\mathrm{NH}_{4}{ }^{+}$; utilize glutamate as dual nitrogen and carbon sources; urease-positive; no growth at 45 and $52{ }^{\circ} \mathrm{C}\left(50 \%\right.$ of the strains of $M$. parafortuitum grow at $45{ }^{\circ} \mathrm{C}$ when isolated, but do not grow after a few transfers); do not utilize raffinose or I,4-butylene glycol as the sole carbon source; do not utilize benzamide and nicotinamide as dual nitrogen and carbon sources; niacin is not formed.

\section{DISCUSSION}

The results of both methods of analysis suggest that $M$. parafortuitum, $M$. aurum and $M$. neoaurum may be regarded as a complex i.e. the $M$. parafortuitum complex, or as three subspecies of the species $M$. parafortuitum. Mycobacterium chubuense and $M$. tokaiense were not separated from each other by the test of separation and were in the same cluster in the dendrogram and hence these two should be regarded as one species, namely $M$. chubuense. The following species are considered as distinct: $M$. parafortuitum, $M$. aichiense, $M$. rhodesiae, $M$. chubuense, $M$. obuense, $M$. gilvum, $M$. duvalii, $M$. flavescens and $M$. vaccae.

\section{REFERENCES}

Bojalil, L. F., Cerbón, J. \& Trujillo, A. (1962). Adansonian classification of mycobacteria. Journal of General Microbiology 28, 333-346.

BöNICKE, R. \& JUHASZ, S. E. (1964). Beschreibung der neuen Species Mycobacterium vaccae n. sp. Zentralblatt für Bakteriologie, Parasitenkunde, Infektionskrankheiten und Hygiene (Abteilung I), Originale A 192, 133-135.

KäPPLER, W. (1965). Acetyl-Naphthylamin-Esterasen-Aktivität von Mykobakterien. Beiträge zur Klinik und Erforschung der Tuberkulose und Lungenkrankheiten 130, I-4.

LehmanN, K. B. \& NeumanN, R. O. (I 899). In Lehmann's Medizinische Handatlanten. X. Atlas und Grundriss der Bakteriologie und Lehrbuch der speziellen bakteriologischen Diagnostik, II, Auflage 2, pp. I-497 (p. 4II). [Cited from Index Bergeyana (1966). Edited by R. E. Buchanan, J. G. Holt and E. F. Lessel, Jr. Baltimore: Williams \& Wilkins.]

Liston, J., WiEBE, W. \& CoLWELL, R. R. (I963). Quantitative approach to the study of bacterial species. Journal of Bacteriology 85, 106I-1070.

SoKal, R. R. \& SNeAth, P. H. A. (1963). Principles of Numerical Taxonomy. San Francisco and London: Freeman and Co.

STANFORD, J. L. \& GUNTHORPE, W. J. (197I). A study of some fast-growing scotochromogenic mycobacteria including species description of Mycobacterium gilvum (new species) and Mycobacterium duvalii (new species). British Journal of Experimental Pathology 52, 627-637.

TsuKamuRA, M. (1966) Adansonian classification of mycobacteria. Journal of General Microbiology 45, 253-273.

TSUKAMURA, M. (I967). Identification of mycobacteria. Tubercle 48, $3 \mathrm{II}-338$.

TsUKAMURA, M. (1968). Classification of scotochromogenic mycobacteria. Japanese Journal of Microbiology $12,63-75$.

TsuKamURA, M. (1969). Identification of Group II scotochromogens and Group III nonphotochromogens of mycobacteria. Tubercle 50, 5I-60.

TsuKamura, M. (197I). Differentiation between Mycobacterium phlei and Mycobacterium thermoresistibile. American Review of Respiratory Disease 103, 280-282.

TsUKAMURA, M. (1972). A new species of rapidly growing, scotochromogenic mycobacteria, Mycobacterium neoaurum Tsukamura n. sp. Medicine and Biology, Tokyo 85, 229-233.

TsukamURA, M. (1973). New species of rapidly growing, scotochromogenic mycobacteria, Mycobacterium chubuense Tsukamura, Mycobacterium aichiense Tsukamura, and Mycobacterium tokaiense Tsukamura. Medicine and Biology, Tokyo 86, 13-17.

TsuKamURA, M. (1976). An approach to numerical identification of bacterial species. Journal of General Microbiology 95, 207-2 2 .

Tsuramura, M. \& Mizuno, S. (1971). Mycobacterium obuense, a rapidly growing scotochromogenic Mycobacterium capable of forming a black product from $p$-aminosalicylate and salicylate. Journal of General Microbiology 68, I29-134.

Tsuramura, M. \& TsuKamURA, S. (1966). Mycobacterium aurum; a new species. Medicine and Biology, Tokyo 72, 270-273. 
Tsukamura, M., Toyama, H. \& Mizuno, S. (1965). Mycobacterium parafortuitum, a new species. Medicine and Biology, Tokyo 70, 232-235.

Tsukamura, M., Mizuno, S., Gane, N. F. F., Mills, A. \& King, L. (1971). Mycobacterium rhodesiae sp. nov. A new species of rapid-growing scotochromogenic mycobacteria. Japanese Journal of Microbiology I5, 407-4I6.

Tsukamura, M., Mizuno, S. \& Murata, H. (1972). Acetyl-naphthylamine esterase activity of mycobacteria. Kekkaku 47, 4I-45. 